\title{
Computational studies on non-nucleoside analogs of pyrimidine as NNRTIs against HIV-1
}

\author{
Ritika Srivastava, Nidhi Singh, Anuradha Singh, Madhu Yadav, Ramendra K Singh* \\ From 2nd International Science Symposium on HIV and Infectious Diseases (HIV SCIENCE 2014) \\ Chennai, India. 30 January - 1 February 2014
}

\section{Background}

HIV is a retrovirus having ss RNA as the genetic material, which gets converted into ds DNA in the presence of reverse transcriptase (RT) enzyme. RT has been found the most attractive target for development of anti HIV-1 agents. Its inhibition is considered as one of the most practical approaches to prevent HIV infection.

\section{Methods}

NNRTIs are non-competitive inhibitors and bind at allosteric site. Designing of non nucleoside analogs of pyrimidine as NNRTIs has been done on the basis of Lipinski's Rule of Five \& using the software DS 3.0. The molecules have been docked with HIV-RT using DS 3.0 in order to generate computational data and assess their suitability.

\section{Results}

Docking experiments have shown good interaction of non nucleoside analogs of pyrimidine as NNRTIs. Analysis of the docking results revealed that these molecules adopted butterfly conformations while interacting at NNIBP of HIV-1 RT \& formed hydrogen bonds with amino acids, Lys101, Lys103, Tyr181, Tyr318 and $\pi$-stacking interactions with Tyr181, Tyr188, Phe227 and $\operatorname{Trp} 229$.

\section{Conclusion}

The molecular modeling revealed the interaction level of these molecules comparable to that of nevirapine. Hence, we predict these molecules as potential NNRTIs against HIV-1 RT.

* Correspondence: rksinghsrk@gmail.com

Nucleic Acids and Antiviral Research Laboratory, Department of Chemistry, University of Allahabad, Allahabad (UP) - 211002, India
Published: 27 May 2014

\section{doi:10.1186/1471-2334-14-S3-E3}

Cite this article as: Srivastava et al.: Computational studies on nonnucleoside analogs of pyrimidine as NNRTIs against HIV-1. BMC Infectious Diseases 2014 14(Suppl 3):E3.
Submit your next manuscript to BioMed Central and take full advantage of:

- Convenient online submission

- Thorough peer review

- No space constraints or color figure charges

- Immediate publication on acceptance

- Inclusion in PubMed, CAS, Scopus and Google Scholar

- Research which is freely available for redistribution
( Biomed Central 